\title{
PENJADWALAN TUTORIAL TATAP MUKA MENGGUNAKAN SISTEM PENDUKUNG KEPUTUSAN
}

\author{
Pismia Sylvi (pismia@ut.ac.id) \\ Universitas Terbuka
}

\begin{abstract}
Effective face-to-face tutorial will be affected by some factors such as number of participants, the scattered locations, the lack of competent tutors, and the poor management system. Specifically, this problem was caused by (i) tutors who teach too many subjects, (ii) the mismanaged scheduling system that a tutor teaches in different classes at the same time. Through decision support system, scheduling is expected to become more effective and efficient. Constraint programming was used as a method to solve problems through mathematical calculation based on prerequisites and limitation. However, the lack of competent tutors remain a major obstacle in running face-to-face tutorial.
\end{abstract}

Keywords: constraint programming, decision support system, tutorial scheduling

\begin{abstract}
ABSTRAK
Efektivitas pelaksanan tutorial tatap muka menjadi berkurang, antara lain akibat besarnya jumlah peserta , tersebarnya lokasi tutorial tatap muka, tidak kompetennya tutor, dan lemahnya sistem pembuatan jadwal tutorial. Masalah ketidakefektifan ini disebabkan oleh (i) adanya tutor yang yang mengajar untuk beberapa matakuliah, (ii) sistem penjadwalan yang tidak baik sehingga terdapat tutor yang mengajar pada beberapa kelas pada waktu yang sama. Dengan demikian penjadwalan tutorial menjadi masalah yang penting dalam pelaksanaan tutorial tatap muka. Melalui Sistem Pendukung Keputusan, penjadwalan tutorial diharapkan dapat menjadi lebih efektif dan efisien. Untuk mencari solusi terhadap persoalan ini, digunakan Constraint programming. Cara ini didasarkan pada perhitungan matematika dengan memperhitungkan batasan-batasan yang ada. Namun demikian, kualitas tutor tetap merupakan kunci permasalahan. Kurangnya tutor yang berkompeten akan mempengaruhi efektivitas tutorial tatap muka.
\end{abstract}

Kata kunci: constraint programming, decision support system, penjadwalan tutorial

Universitas Terbuka (UT) merupakan salah satu institusi pendidikan tinggi yang menerapkan sistem pendidikan terbuka dan jarak jauh, dengan Unit Program Belajar Jarak Jauh (UPBJJ) sebagai unit pelaksana teknis di daerah. Mahasiswa UT diharapkan dapat belajar secara mandiri dan UT memfasilitasi mereka dengan bahan ajar cetak dan suplemen yang dirancang khusus untuk belajar mandiri, disamping adanya layanan bantuan belajar berupa tutorial (tatap muka, online, siaran televisi, dan radio).

Khusus bagi mahasiswa program Pendidikan Dasar (Pendas), yaitu Program Studi (prodi) S-1 Pendidikan Guru SD (PGSD) dan S-1 Pendidikan Guru PAUD (PGPAUD), secara otomatis mereka mendapatkan layanan bantuan belajar berupa Tutorial Tatap Muka (TTM) untuk 2-4 mata 
kuliah setiap semesternya. Pelaksanaan TTM tersebut membutuhkan beberapa persiapan, diantaranya: rekrutmen tutor, pemilihan dan penetapan lokasi tutorial; penyusunan dan penetapan jadwal tutorial sesuai dengan kebutuhan kelas dan mata kuliah per lokasi tutorial.

UPBJJ-UT Surabaya, salah satu dari 37 UPBJJ yang ada, memiliki jumlah mahasiswa yang cukup besar, yang tersebar di 18 kabupaten/kota. Jumlah dan penyebaran mahasiswa Pendas di UPBJJ-UT Surabaya pada masa registrasi 2008.1 hingga 2010.2 dapat dilihat dalam Tabel 1.

Tabel 1. Jumlah Mahasiswa Pendas di UPBJJ-UT Surabaya pada Masa Registrasi 2008.1 sampai dengan 2010.2 .

\begin{tabular}{rlrrrrrr}
\hline \multirow{2}{*}{ NO } & \multirow{2}{*}{ KABKO } & \multicolumn{7}{c}{ MASA REGISTRASI } \\
\cline { 2 - 7 } & 2008.1 & 2008.2 & 2009.1 & 2009.2 & 2010.1 & 2010.2 \\
\hline 1 & SURABAYA & 712 & 746 & 654 & 521 & 587 & 704 \\
2 & SIDOARJO & 2386 & 2058 & 2086 & 2279 & 2131 & 2144 \\
3 & Kota MOJOKERTO & 63 & 39 & 39 & 423 & 0 & 249 \\
4 & Kab MOJOKERTO & 1547 & 2051 & 1922 & 1541 & 1778 & 1643 \\
5 & JOMBANG & 1493 & 1586 & 1129 & 929 & 895 & 692 \\
6 & Kota MADIUN & 420 & 401 & 463 & 527 & 509 & 579 \\
7 & Kab MADIUN & 806 & 809 & 829 & 597 & 554 & 529 \\
8 & PONOROGO & 1113 & 1372 & 1424 & 1277 & 1201 & 1062 \\
9 & MAGETAN & 521 & 577 & 639 & 475 & 407 & 374 \\
10 & NGAWI & 1038 & 1164 & 1236 & 1226 & 1419 & 1500 \\
11 & BOJONEGORO & 1722 & 2248 & 2134 & 1875 & 1673 & 1420 \\
12 & TUBAN & 533 & 675 & 591 & 323 & 289 & 291 \\
13 & LAMONGAN & 807 & 757 & 721 & 626 & 489 & 504 \\
14 & GRESIK & 1423 & 1373 & 1375 & 1105 & 907 & 842 \\
& Bawean & 21 & 64 & 64 & 64 & 0 & 0 \\
15 & BANGKALAN & 1400 & 1724 & 1398 & 1450 & 1452 & 1515 \\
16 & SAMPANG & 1247 & 1414 & 1625 & 1638 & 1799 & 1956 \\
& Depag & 0 & 122 & 148 & 279 & 0 & 0 \\
17 & PAMEKASAN & 1856 & 2480 & 2435 & 2333 & 2399 & 2375 \\
18 & SUMENEP & 1048 & 1404 & 1407 & 900 & 1026 & 877 \\
\hline & JUMLAH & 20156 & 23064 & 22319 & 20388 & 19515 & 19256 \\
\hline SUyyyyyyyyyy
\end{tabular}

Sumber data: Bagian Registrasi UPBJJ-UT Surabaya

Di setiap kabupaten/kota, mahasiswa yang berasal dari program studi dan semester yang sama dikelompokkan dalam satu kelompok belajar (pokjar) yang berisi sekitar 30 mahasiswa. Jumlah mata kuliah yang diberikan dalam satu semester tergantung pada prodi dan semesternya. Dengan terbatasnya jumlah tutor yang sesuai sedangkan lokasi, kelas, dan mata kuliah yang ditutorialkan sangat banyak, penjadwalan tutorial di UPBJJ-UT Surabaya menjadi hal yang cukup rumit untuk diselesaikan, sehingga membutuhkan waktu yang cukup lama (hingga dua bulan) dan melibatkan petugas yang banyak (delapan orang).

Beberapa tulisan yang membahas sistem penjadwalan merupakan penjadwalan untuk satu lokasi (kampus) di perguruan tinggi tatap muka. Artkel ini mencoba menawarkan sistem penjadwalan 
untuk perguruan tinggi terbuka jarak jauh seperti UT yang memiliki banyak lokasi, banyak mahasiswa dan banyak matakuliah.

\section{Sistem Pendukung Keputusan}

Sistem Pendukung Keputusan (SPK) merupakan sistem berbasis komputer interaktif, yang mendukung proses pengambilan keputusan dengan mendayagunakan data dan model untuk menyelesaikan masalah tidak terstruktur (Morton, 1971). Keen dan Morton (1978) menyebutkan bahwa SPK menggabungkan sumber daya intelektual dari individu-individu dengan kemampuan komputer untuk meningkatkan kualitas dari keputusan-keputusan. Dengan demikian, SPK merupakan suatu sistem pendukung keputusan berbasis komputer bagi pengambil keputusan untuk masalah-masalah semi terstruktur.

Pendekatan ilmiah untuk SPK adalah sebagai berikut: (1) Mendefinisikan masalah, (2) Menggolongkan masalah ke dalam suatu kategori standar, (3) Membangun sebuah model matematika, (4) Menemukan dan mengevaluasi solusi potensial dari model, (5) Memilih dan merekomendasikan sebuah solusi dari permasalahan (Turban, Aronson \& Liang, 2005).

\section{Constraint Programming}

Menurut Barták (2003), kesulitan dalam penjadwalan akademik sebagai suatu aktifitas pengambilan keputusan adalah tidak terstrukturnya sumber daya maupun tugas-tugas dan banyaknya himpunan batasan yang harus diasumsikan dalam memodelkan permasalahan. Untuk memperkecil kesulitan karena adanya batasan-batasan tersebut maka digunakan constraint programming.

Constraint Programming (CP) merupakan pendekatan perhitungan atau komputasi matematis atas masalah-masalah yang berkaitan dengan batasan-batasan dari variabel-variabel, dengan tujuan mencari solusi yang memenuhi batasan-batasan tersebut (Muhyi, 2008). Dalam Barták (1999) diungkapkan bahwa masalah yang harus diselesaikan dalam CP disebut sebagai Constraint Satisfaction Problem (CSP). Pemodelan CSP yang lengkap terdiri dari himpunan variabel (data yang nilainya dapat berubah-ubah), himpunan domain (nilai yang mungkin untuk setiap variabel), dan himpunan constraint (batasan yang harus dipenuhi oleh setiap variabel).

Metode ini lebih baik dalam hal pemodelan karena tidak terkait dengan bagaimana cara mendapatkan solusi (Barták, 1998). Dalam metode ini, solusi bisa diperoleh cukup dengan menspesifikasikan batasan-batasan yang harus diselesaikan tanpa pemodelan yang detail mengenai masalah terserbut. Muhyi (2008) juga menyebutkan bahwa yang menjadi solusi atau kumpulan solusi dari CSP adalah nilai-nilai dari variabel itu sendiri. Ada beberapa kemungkinan solusi yang diperoleh, yaitu:

(1) Satu set solusi saja, biasanya diperoleh dari pencarian pertama;

(2) Seluruh solusi (himpunan solusi) yang bisa diperoleh;

(3) Himpunan solusi yang paling optimum, yang bisa berarti maksimum, minimum, atau mendekati suatu nilai tertentu.

\section{Pengembangan Sistem}

Menurut Turban dan Liang (2005), suatu proyek pengembangan sistem meliputi semua kegiatan yang dilakukan sejak semua persyaratan penting diketahui sampai sistem yang dihasilkan dapat diimplementasikan sepenuhnya dan diterima oleh pengguna akhir. Proses tersebut bisa berupa banyak tahap dan berjalan dalam periode yang lama. 
Kerangka kerja System Development Life Cycle (SDLC) memberikan serangkaian aktifitas untuk diikuti oleh perancang dan pengembang sistem. SDLC terdiri dari serangkaian fase, dengan setiap fase selalu menggunakan hasil dari fase sebelumya. Fase-fase dalam SDLC adalah: (1) Perencanaan Proyek: inisiasi, uji kelayakan, merancang jadwal, mendapat persetujuan proyek, (2) Analisis: memahami kebutuhan bisnis dan persyaratan pemrosesan, (3) Desain: mendefinisikan sistem penyelesaian berdasarkan persyaratan dan analisis keputusan, (4) Implementasi: konstruksi, pengujian, pelatihan pengguna, dan instalasi sistem baru, dan (5) Dukungan: menjaga sistem tetap berjalan dan selalu diperbaiki.

Ada lima langkah dalam Kerangka kerja SDLC yang digunakan sebagai pendekatan penyelesaian masalah (problem solving) yaitu:

(1) Memahami sistem penjadwalan tutorial lama (yang saat ini berlangsung) di UPBJJ-UT Surabaya

(2) Mengidentifikasi masalah dalam penjadwalan tutorial di UPBJJ-UT dan persyaratan yang harus dipenuhi untuk menyelesaikan

(3) Mengembangkan model untuk menyelesaikan masalah dengan menggunakan metode $C P$

(4) Membuat software dengan bahasa C\# berdasarkan model yang telah dikembangkan

(5) Mengimplementasikan sistem penjadwalan yang baru, merawat, dan memperbaiki sistem tidak dibahas dalam tulisan ini.

\section{HASIL DAN PEMBAHASAN}

UPBJJ-UT Surabaya menyelenggarakan TTM Program Pendas dalam dua tahap pada setiap masa registrasi karena jumlah mahasiswa yang sangat besar. Tahap pertama merupakan TTM untuk mahasiswa semester lanjut, sedangkan tahap kedua diselenggarakan untuk mahasiswa baru.

Perancangan jadwal dilakukan oleh tim yang terdiri dari delapan petugas dan salah satunya sebagai Supervisor. Supervisor inilah yang bertanggung-jawab mulai dari merancang jadwal tutorial sampai menjadi sebuah jadwal tutorial final.

Sebelum pembuatan jadwal, tim harus mengidentifikasi jumlah pokjar/ kelas pada setiap prodi dan semester di setiap kabupaten/kota. Berdasarkan data ini, tim dapat menentukan berapa banyak tugas dan berapa jumlah tutor yang diperlukan.

Untuk merancang jadwal, ke-18 kabupaten/kota tersebut dikelompokkan menjadi empat ring dan masing-masing ring dirancang oleh dua anggota tim. Ring I meliputi Surabaya, Sidoarjo, Mojokerto, and Jombang; Ring II meliputi Madiun, Ponorogo, Magetan, and Ngawi; Ring III meliputi Bojonegoro, Tuban, Lamongan, and Gresik; Ring IV meliputi Bangkalan, Sampang, Pamekasan, and Sumenep. Rancangan jadwal dari keempat ring tersebut selanjutnya diserahkan ke Supervisor untuk digabungkan dan diperiksa apakah: (1) terdapat tutor yang memberikan tutorial di pokjar yang berbeda atau mata kuliah yang berbeda pada waktu yang sama, (2) terdapat dua atau lebih tutor yang memberikan tutorial di pokjar yang sama pada waktu yang sama.

Jika Supervisor masih menemukan masalah dalam rancangan jadwal, dia harus memperbaiki dengan mengganti tutor atau mengatur ulang rancangan jadwal tersebut. Hal ini biasanya dilakukan berulang kali sebelum mendapatkan jadwal tutorial final.

Sistem penjadwalan tutorial secara lengkap (dari perencanaan hingga monitoring-evaluasi) ditunjukkan pada Gambar 1. 


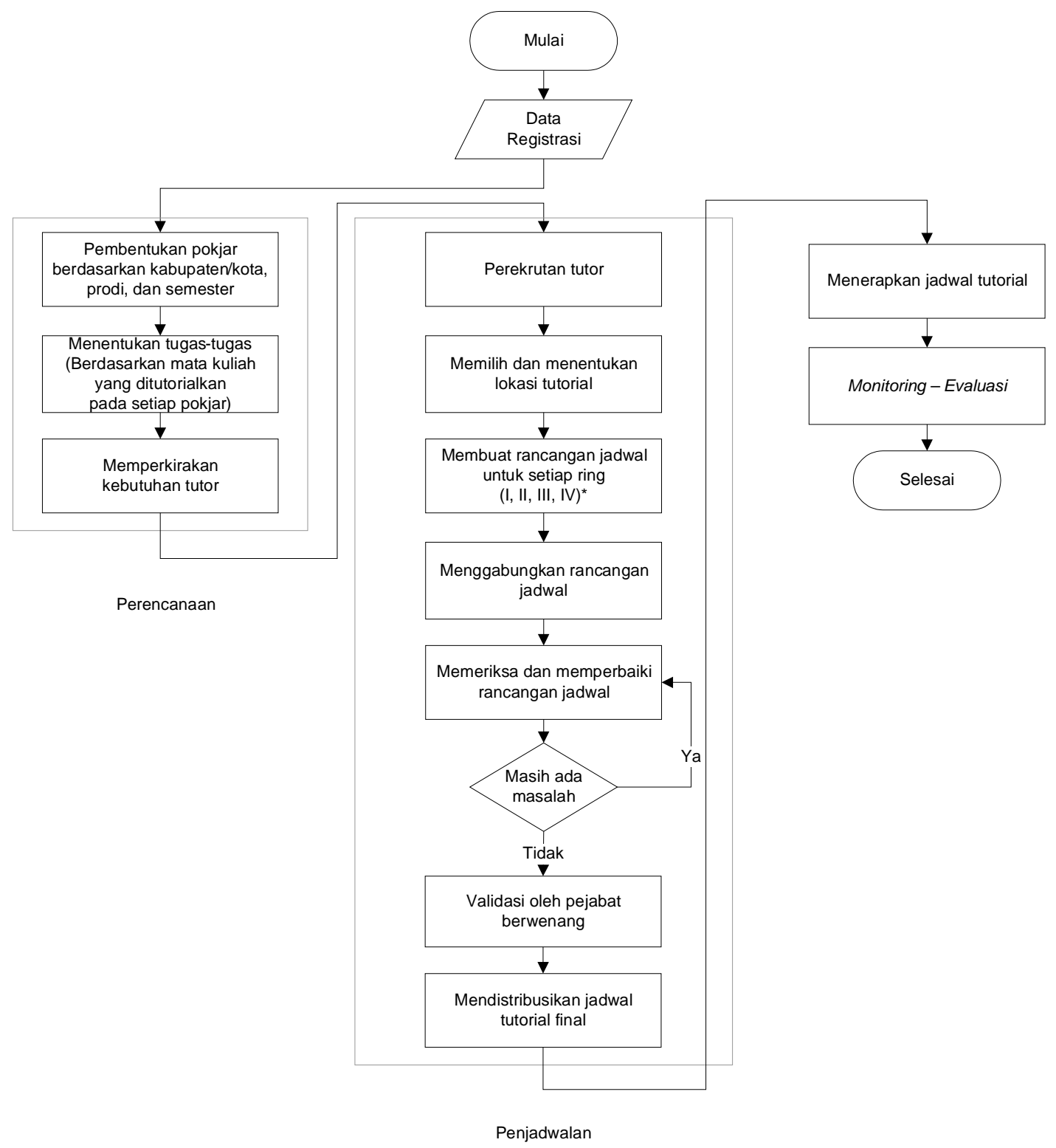

Gambar 1. Diagram alir sistem penjadwalan tutorial lama

\section{Permasalahan dan Persyaratan Penyelesaian}

Permasalahan yang muncul dalam sistem penjadwalan yang lama adalah banyaknya waktu yang diperlukan untuk mendapatkan jadwal tutorial final (sekitar 5 minggu) dan banyaknya petugas (dalam tim) yang terlibat dalam pembuatannya.

Tim tersebut harus mengatur alokasi tutor, yaitu pemasangan tutor dengan tugas, dan penjadwalan tutor, yaitu mengatur urutan waktu tutorial dari setiap tutor. Perbaikan rancangan jadwal 
hingga didapatkan jadwal tutorial final dilakukan berulang kali. Dengan demikian, sebuah sistem penjadwalan yang baru merupakan suatu kebutuhan.

Batasan (constraints) dalam sistem penjadwalan tutorial yaitu:

(1) tutor hanya dapat memberikan tutorial untuk mata kuliah yang sesuai dengan kompetensinya;

(2) terdapat 10 semester untuk prodi PGSD dan 9 semester untuk prodi PGPAUD;

(3) setiap semester dari setiap prodi memiliki mata kuliah-mata kuliah tertentu yang yang ditutorialkan;

(4) pokjar-pokjar diberi nama dengan huruf besar ( $A, B, C$, dan seterusnya) tergantung pada jumlah pokjar dalam setiap semester dan prodi di setiap kabupaten/kota;

(5) setiap pokjar mendapatkan tutorial paling banyak tiga mata kuliah dalam sehari;

(6) setiap tutor memberikan tutorial paling banyak untuk tiga mata kuliah dalam sehari;

(7) tutor tidak dapat memberikan tutorial di dua atau lebih kabupaten/kota.

\section{Dimensi}

Pengertian dimensi pada artikel ini adalah data yang diperlukan dalam penjadwalan tutorial (Muhyi, 2008). Dalam perhitungan, dimensi ini menggunakan indeks angka integer yang merepresentasikan isi anggotanya. Jadi dimensi ini lebih tepat jika dimodelkan sebagai array. Misalkan dimensi $D$ adalah himpunan semua huruf, maka $D=\{a, b, c, \ldots, z\}$. Dalam perhitungan $C P$, maka $D$ akan menjadi array, dan dinotasikan sebagai:

- $D[0]=\mathrm{a}$

- $D[1]=b$

- $D[2]=c$

- $\quad .$.

- $D[23]=z$

Hasil penelaahan data-data yang diperlukan untuk membentuk CSP, adalah dimensi-dimensi dasar dalam penjadwalan tutorial yang berupa variabel-variabel dan domain-domain sebagai berikut. (1) Variabel Kabko $(K)$, adalah kabupaten/kota yang ada, dengan domain:
a. Kota Surabaya
b. Kabupaten Sidoarjo
c. Kota Mojokerto
d. Kabupaten Mojokerto
e. Kabupaten Jombang
f. Kota Madiun
g. Kabupaten Madiun
h. Kabupaten Ponorogo
i. Kabupaten Magetan
j. Kabupaten Ngawi
k. Kabupaten Bojonegoro
I. Kabupaten Tuban
m. Kabupaten Lamongan
n. Kabupaten Gresik 
0. Kabupaten Bangkalan

p. Kabupaten Sampang

q. Kabupaten Pamekasan

r. Kabupaten Sumenep

(2) Variabel Jurusan (J), adalah jurusan/program studi yang ada, dengan domain:

a. S-1 PGSD (Kode: PGSD)

b. S-1 PGPAUD (Kode: PAUD).

(3) Variabel Semester (S), adalah semester yang ada, dengan domain: semester 1, 2.., 10.

(4) Variabel Kelas $(C)$, yang menunjukkan kelas (kelompok belajar/pokjar) yang akan dibuka, dengan domain: Kelas A, B, C, dan seterusnya tergantung jumlah pokjar yang terbentuk di kabko tersebut pada prodi dan semester yang sama.

(5) Variabel Mata kuliah $(M)$, adalah mata kuliah yang akan ditutorialkan kepada mahasiswa, dengan domain misal:

a. Keterampilan Berbahasa Indonesia SD (Kode: PDGK4101)

b. Metode Pengembangan Kognitif (Kode: PAUD4101), dan seterusnya.

(6) Variabel Tutor $(T)$, adalah tutor yang akan memberikan tutorial, dengan domain misal:

a. Nurmi Frida Dorintan, B.P. Dr., M.Pd. (ID: 71000001)

b. Dyah Argarini, M.Pd. (ID: 71000003), dan seterusnya.

(7) Variabel Pertemuan $(P)$ adalah jam pertemuan tutorial, dengan domain:

a. Jam Pertemuan I

b. Jam Pertemuan II

c. Jam Pertemuan III

\section{Hubungan Antar Dimensi}

Dari dimensi-dimensi diatas, ada hubungan khusus dari beberapa dimensi yang harus berkaitan. Hubungan-hubungan tersebut adalah:

(1) Tutor-Mata Kuliah (TM), adalah mata kuliah ampuan dari seorang tutor, misal:

a. Nurmi Frida Dorintan, B.P. Dr., M.Pd. (71000001), memiliki mata kuliah ampuan Metode Penelitian (IDIK4007), Tugas Akhir Program/TAP (PDGK4500), dan Pendidikan Lingkungan Hidup (PEBI4223);

b. Dyah Argarini, M.Pd. (71000003), memiliki mata kuliah ampuan Metode Penelitian (IDIK4007), Bahasa Inggris untuk Guru SD (PDGK4304), dan Penulisan Karya IImiah (PDGK4402);

dan seterusnya.

(2) Jurusan-Semester (JS), adalah semester yang ada di suatu jurusan/prodi, yaitu: PGSD Semester 1, PGSD Semester 2, PGSD Semester 3, ..., PGSD Semester 10, PAUD Semester 1, PAUD Semester 2, PAUD Semester 3, ..., PAUD Semester 9.

(3) Jurusan-Semester-Mata kuliah (JSM), adalah mata kuliah wajib tutorial pada suatu semester di suatu prodi, misal:

a. PGSD Semester 1, mata kuliah wajib tutorialnya adalah Keterampilan Berbahasa Indonesia SD (PDGK4101), Konsep Dasar IPS (PDGK4102), dan Konsep Dasar IPA di SD (PDGK4103);

b. PGSD Semester 2, mata kuliah wajib tutorialnya adalah Strategi Pembelajaran di SD (PDGK4105), Praktikum IPA di SD (PDGK4107), dan Matematika (PDGK4108); dan seterusnya. 
(4) Kota-Semester-Jurusan-Kelas (KSJC), adalah kelas/pokjar yang terbentuk pada suatu kabko dalam semester dan jurusan/prodi yang sama, misal:

a. Kota Surabaya, untuk PGSD semester 2 ada 2 kelas yaitu $A, B$;

b. Kabupaten Sidoarjo, untuk PGSD semester 2 ada 3 kelas yaitu $A, B, C$; dan seterusnya.

Cara notasi hubungan antar dimensi menjadi bentuk array adalah sebagai berikut. Nilai anggota array adalah 1 (satu) jika ada relasi antar anggota dimensi-dimensi tersebut, dan 0 (nol) jika tidak ada relasi antar anggota dimensi-dimensi tersebut. Misal pada Mata Kuliah (M) dan Jurusan (J), dimana

$$
\begin{aligned}
& M[0]=\text { PDGK4101 } \\
& M[1]=\text { PDGK4102 } \\
& M[2]=\text { PDGK4103 } \\
& \text { dan seterusnya; } \\
& J[0]=\text { PGSD } \\
& J[1]=\text { PAUD }
\end{aligned}
$$

maka hubungan antara Mata Kuliah (M) dan Jurusan (J) dapat ditulis dalam bentuk array sebagai berikut

$$
\begin{aligned}
& M J[0][0]=M J[P D G K 4101][P G S D]=1 \\
& M J[1][0]=M J[P D G K 4102][P G S D]=1 \\
& M J[0][1]=M J[P D G K 4101][P A U D]=0, \text { dan seterusnya. }
\end{aligned}
$$

\section{Variabel dan Syarat Solusi}

Untuk mencari solusi dalam CSP, perlu didefinisikan variabel solusi $X$, yang memiliki sejumlah dimensi yang masing-masing memiliki indeks sejumlah data dari dimensi yang bersangkutan. Dengan demikian, variabel $X$ dapat ditulis dengan notasi array sebagai berikut:

atau

$$
\text { X[Kota][Jurusan][Semester][Kelas][Mata Kuliah][Tutor][Pertemuan] }
$$

$$
X[K][J][S][C][M][T][P]
$$

Sebagaimana dijelaskan sebelumnya, maka $X$ juga memiliki nilai 1 (satu) jika ada relasi antar anggota dimensi-dimensinya, dan 0 (nol) jika tidak ada relasi antar anggota dimensi-dimensinya. $X$ yang bernilai 1 inilah yang menjadi solusi dalam penyusunan jadwal tutorial.

Variabel $X$ harus memenuhi seluruh batasan-batasan pada hubungan antar variabel sebelumnya, yang artinya bahwa variabel $X$ bernilai lebih kecil atau sama dengan hubungan antar variabel yang bersesuaian. Misal sebuah data pada Tutor-Mata Kuliah (TM), dimana tutor $t$ memberikan tutorial untuk mata kuliah $m$, maka variabel $X$ harus memenuhi syarat

$$
X[K][]][S][C][M][T][P] \leq T M[t][m]
$$


Dengan cara ini maka dapat dijamin bahwa variabel $X$ akan selalu konsisten dengan batasanbatasan yang ditetapkan.

Langkah selanjutnya adalah menetapkan batasan-batasan atau syarat-syarat (constraints) sebagai berikut.

a. $X$ adalah bernilai integer, yang nilainya adalah 0 (nol) atau 1 (satu), dirumuskan sebagai

$$
0 \leq X[K][J][S][C][M][T][P] \leq 1, X \in \text { int }
$$

b. Untuk tiap nilai $X$ harus lebih kecil atau sama dengan data pada hubungan Tutor-Mata Kuliah yang bersesuaian, dirumuskan sebagai

$$
X[K][J][S][C]\left[M_{m}\right]\left[T_{t}\right][P] \leq T M[t][m]
$$

c. Untuk tiap nilai $X$ harus lebih kecil atau sama dengan data pada hubungan Jurusan-Semester yang bersesuaian, dirumuskan sebagai

$$
\left.X[K]\left[J_{j}\right]\left[S_{S}\right][C][M][T][P] \leq J S[]\right][S]
$$

d. Untuk tiap nilai $X$ harus lebih kecil atau sama dengan data pada hubungan Jurusan-SemesterMata kuliah yang bersesuaian, dirumuskan sebagai

$X[K]\left[J_{j}\right]\left[S_{s}\right][C]\left[M_{m}\right][T][P] \leq J S M[j][S][m]$

e. Untuk tiap nilai $X$ harus lebih kecil atau sama dengan data pada hubungan Kota-SemesterJurusan-Kelas yang bersesuaian, dirumuskan sebagai

$X\left[K_{k}\right]\left[J_{j}\right]\left[S_{s}\right]\left[C_{c}\right][M][T][P] \leq K S J C[k][s][j][C]$

f. Satu kelas dalam satu hari maksimum mendapat tiga jam pertemuan tutorial, dengan mata kuliah yang berbeda-beda. Dengan kata lain, nilai $X$ untuk jam pertemuan tertentu dan mata kuliah tertentu harus lebih kecil atau sama dengan 1 (satu), dirumuskan sebagai

$X[K]\left[J_{j}\right][S]\left[C_{c}\right]\left[M_{m}\right][T][P] \leq 1$

g. Satu tutor tutor dapat memberikan tutorial maksimum tiga jam pertemuan. Dengan kata lain, nilai $X$ untuk tutor tertentu dan jam pertemuan tertentu harus lebih kecil atau sama dengan 1 (satu), dirumuskan sebagai

$X[K]\left[J_{j}\right][S][C][M]\left[T_{t}\right][P] \leq 1$

h. Seorang tutor dapat memberikan tutorial maksimum di satu kabko. Dengan kata lain, nilai $X$ untuk tutor tertentu dan kabko tertentu harus lebih kecil atau sama dengan 1 (satu), dirumuskan sebagai

$X\left[K_{k}\right][J][S][C][M]\left[T_{t}\right][P] \leq 1$

Setelah terbentuk suatu CSP, langkah selanjutnya adalah mencari solusi yang tepat untuk permasalahan tersebut dengan menggunakan SPK berbasis komputer yang mengunakan bahasa pemrograman C\#. 


\section{Implementasi}

Ada lima database yang digunakan dalam aplikasi ini, yaitu database Tutor, database TutorMata Kuliah, database Kelas, database Mata Kuliah, dan database Lain-lain. Database Tutor meliputi Nomor ID Tutor, Nama Tutor, Instansi Tutor, dan Nomor handphone (HP) Tutor. Database Tutor-Mata Kuliah meliputi No. ID Tutor dan Kode Mata Kuliah yang diampu tutor. Database Kelas meliputi Nama Kabko, Jurusan/Prodi, Semester, Jumlah Pokjar/Kelas. Database Mata Kuliah meliputi Jurusan/Prodi, Semester, Kode Mata Kuliah, Nama Mata Kuliah, dan Jumlah SKS. Database Lainlain meliputi Nama Kabko, Nama dan Nomor HP Pengurus Pokjar, Nama dan Nomor HP Penanggungjawab Wilayah.

Kelima database tersebut menjadi masukan dalam proses penyusunan jadwal tutorial, sekaligus sebagai penyimpanan jika ada perubahan terhadap data yang ada. Garis besar penggunaan database dalam penyusunan jadwal tutorial ini dapat dilihat pada Gambar 2.

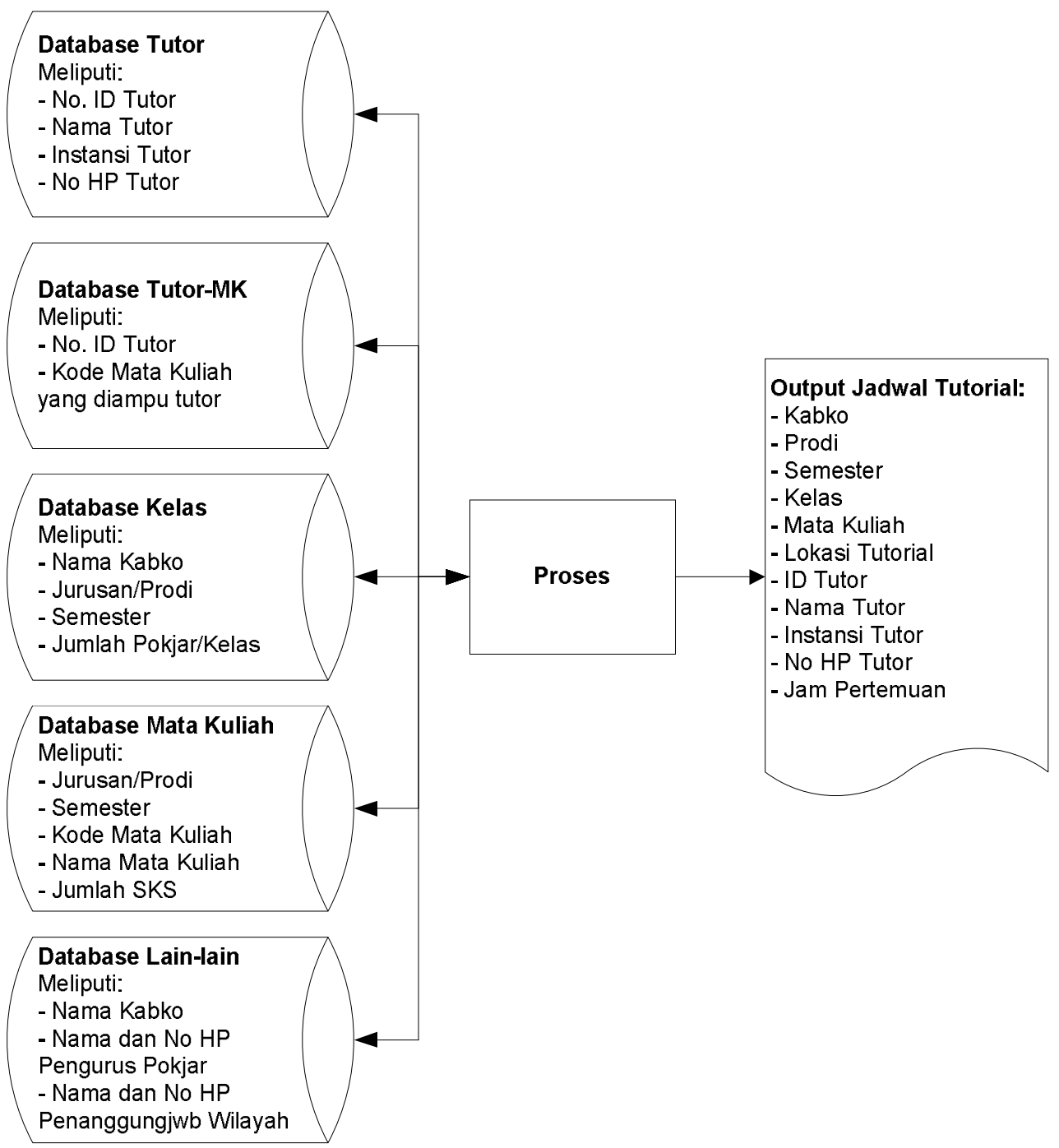

Gambar 2. Konsep database 
Selanjutnya Supervisor dapat membuat jadwal tutorial hanya dalam beberapa menit dengan menggunakan sistem penjadwalan tutorial yang baru. Contoh keluaran (output) dari program dapat dilihat pada Gambar 3 dan Gambar 4. Kendala yang masih muncul dalam sistem baru ini adalah kurangnya tutor yang memiliki kompetensi yang sesuai dengan mata kuliah yang ditutorialkan, sehingga masih ada beberapa tugas yang belum ada tutornya.

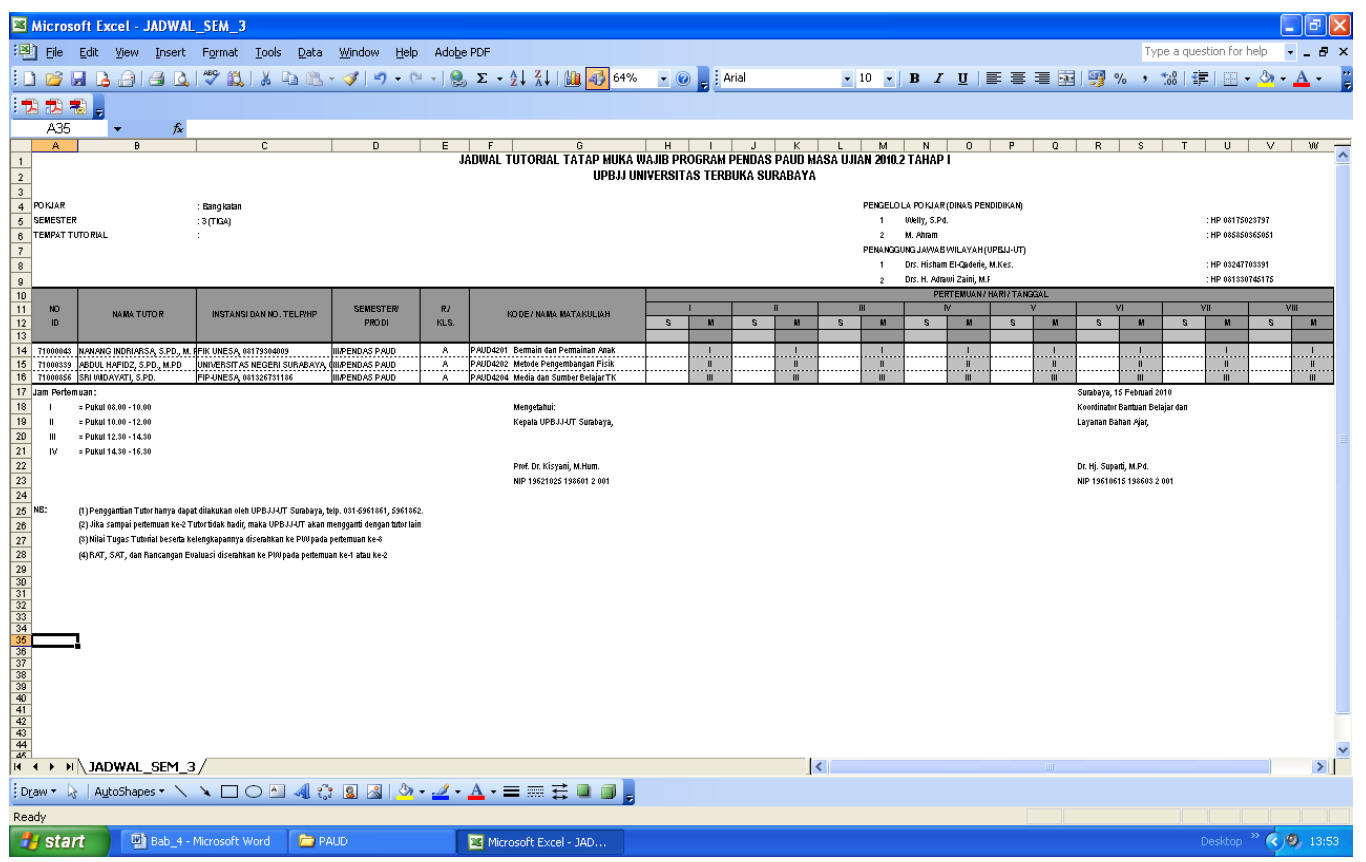

Gambar 3. Jadwal Tutorial untuk PGPAUD Semester 3 di Bangkalan

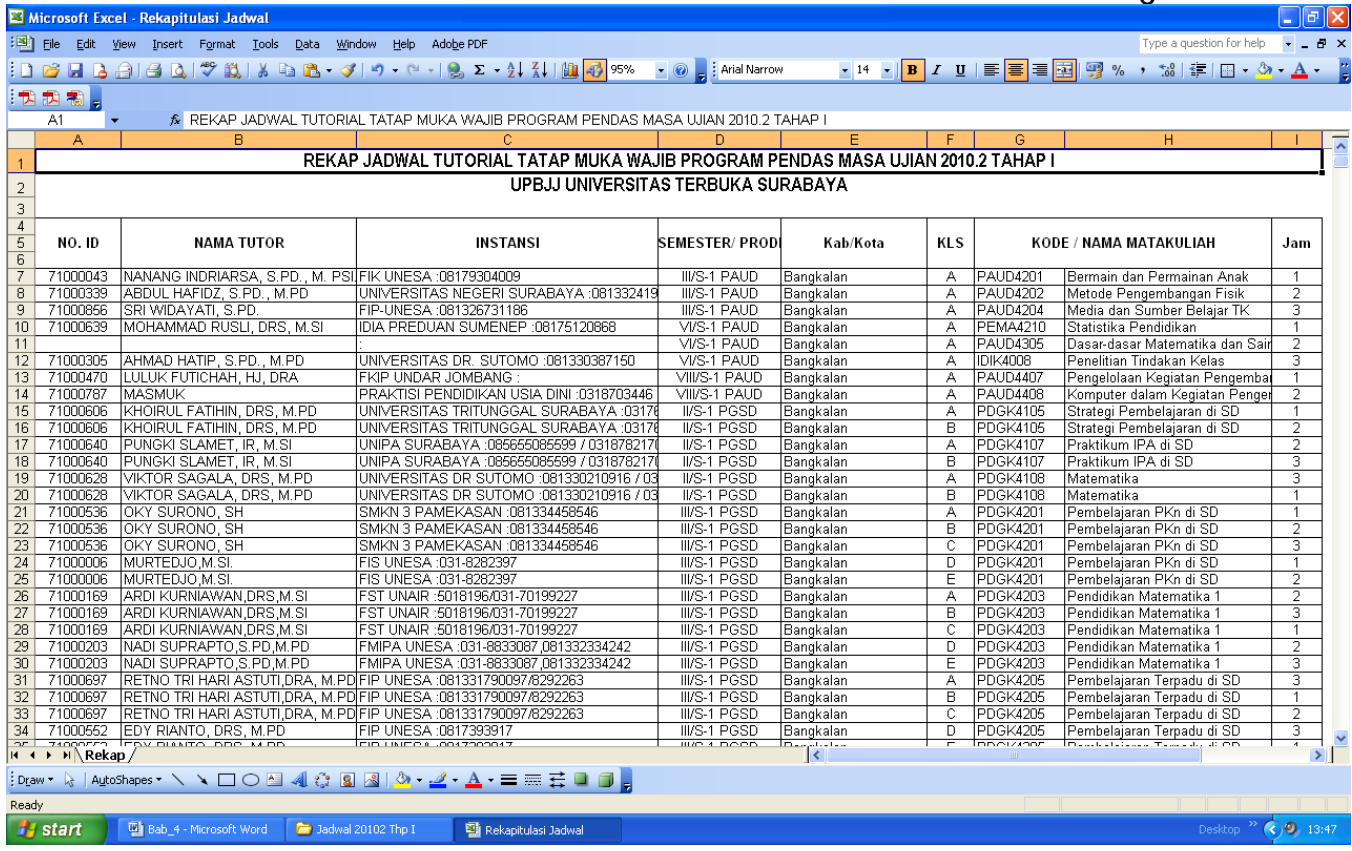

Gambar 4. Rekap jadwal tutorial 


\section{PENUTUP}

Penjadwalan tutorial pada sistem lama membutuhkan banyak waktu dan melibatkan banyak petugas untuk memperoleh jadwal final. Dengan menerapkan Sistem Pendukung Keputusan pada sistem baru, penjadwalan dapat dilakukan dalam waktu yang sangat singkat dan hanya melibatkan satu petugas saja. Petugas cukup melengkapi database yang dibutuhkan dalam penjadwalan, dan selanjutnya dengan memanfaatkan software yang dikembangkan dengan metode Constraint Programming (CP), jadwal final dapat diperoleh dalam waktu kurang dari lima menit. Jumlah tutor dengan kompetensi yang sesuai dengan mata kuliah yang ditutorialkan tetap menjadi kendala utama dalam penjadwalan dengan sistem baru, sebagaimana yang terjadi dengan sistem lama.

\section{REFERENSI}

Barták, R. (2003). Constraint-based Scheduling: An Introduction for Newcomers, In Kadar, Monostori, and Morel (eds.) Intelligent Manufacturing Systems 2003, IFAC Publications, Elsevier Science, pp. 69--74.

Barták, R. (1999). Constraint Programming: In Pursuit of the Holly Grail. Proc. of the Week of Doctoral Students (WDS99), Part IV 1999, pp.555--564.

Barták, R. (1998). On-Line Guide to Contstraint Programming. (Online). Diambil 14 Oktober 2010, dari (http://ktiml.mff.cuni.cz/ bartak/constraints/.

Keen, P.G.W., \& M.S. Morton. (1978). Decision support systems: An organizational perspective. reading, MA: Addison-Wesley.

Muhyi, Y. (2008). Penjadwalan kuliah otomatis dengan constraint programming. Seminar Nasional Teknologi Informasi (SNASTI) 2008, STIKOM Surabaya.

Morton, M.S. (1971). Management decision systems: Computer-based support for decision making. Cambridge, MA: Harvard University, Devision of Research.

Turban, E., Aronson, J.E., \& Liang, T.P. (2005). Decision support systems and intelligent systems (7th ed). New Jersey: Pearson Education. 